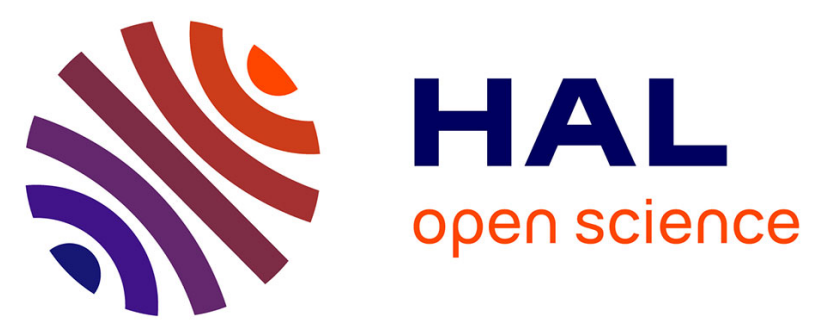

\title{
Reframing nuclear power in the UK energy debate: nuclear power, climate change mitigation and radioactive waste
}

\author{
K. Bickerstaff, I. Lorenzoni, N.F. Pidgeon, W. Poortinga, P. Simmons
}

\section{To cite this version:}

K. Bickerstaff, I. Lorenzoni, N.F. Pidgeon, W. Poortinga, P. Simmons. Reframing nuclear power in the UK energy debate: nuclear power, climate change mitigation and radioactive waste. Public Understanding of Science, 2008, 17 (2), pp.145-169. 10.1177/0963662506066719 . hal-00571101

\author{
HAL Id: hal-00571101 \\ https://hal.science/hal-00571101
}

Submitted on 1 Mar 2011

HAL is a multi-disciplinary open access archive for the deposit and dissemination of scientific research documents, whether they are published or not. The documents may come from teaching and research institutions in France or abroad, or from public or private research centers.
L'archive ouverte pluridisciplinaire HAL, est destinée au dépôt et à la diffusion de documents scientifiques de niveau recherche, publiés ou non, émanant des établissements d'enseignement et de recherche français ou étrangers, des laboratoires publics ou privés. 


\title{
Reframing nuclear power in the UK energy debate: nuclear power, climate change mitigation and radioactive waste
}

\author{
K. Bickerstaff, I. Lorenzoni, N.F. Pidgeon, W. Poortinga and P. Simmons
}

In the past decade, human influence on the climate through increased use of fossil fuels has become widely acknowledged as one of the most pressing issues for the global community. For the United Kingdom, we suggest that these concerns have increasingly become manifest in a new strand of political debate around energy policy, which reframes nuclear power as part of the solution to the need for low-carbon energy options. A mixed-methods analysis of citizen views of climate change and radioactive waste is presented, integrating focus group data and a nationally representative survey. The data allow us to explore how UK citizens might now and in the future interpret and make sense of this new framing of nuclear power-which ultimately centers on a risk-risk trade-off scenario. We use the term "reluctant acceptance" to describe how, in complex ways, many focus group participants discursively re-negotiated their position on nuclear energy when it was positioned alongside climate change. In the concluding section of the paper, we reflect on the societal implications of the emerging discourse of new nuclear build as a means of delivering climate change mitigation and set an agenda for future research regarding the (re)framing of the nuclear energy debate in the UK and beyond.

\section{Introduction}

In the past decade, human influence on the climate through increased use of fossil fuels and changes in land use has become widely acknowledged as one of the most pressing issues for the global community. The attention given to climate change by scientists, environmental activists and policymakers has put it firmly on the policy agenda, and the abnormally warm years on record in the 1990s validated these changes (Hulme et al., 2002). The influential Intergovernmental Panel on Climate Change (IPCC) maintains that "the balance of evidence suggests that there is a discernible human influence on the global climate" (Houghton et al., 1996: 5). In the United Kingdom, summers will, overall, be hotter and drier, winters warmer and wetter (Hulme et al., 2002). These seasonal changes could impinge on water resource availability, increase risks of flooding (Evans et al., 2004) and alter landscapes, with consequent effects on agricultural, industrial, health and financial sectors (DEFRA, 2001).

The international community has become increasingly aware that action is needed to address the threats posed by a changing climate. Those parties that have signed up to the Kyoto 
Protocol are committed to reducing emissions of six main greenhouse gases (GHGs) by roughly 5 percent from 1990 levels by 2008-12. Targets are set individually for most of the developed nations. The UK is committed to a 12.5 percent cut in the six main GHG emissions and is close to meeting this target (HM Government, 2006). The UK government is taking a lead in promoting responses at home and abroad (DEFRA, 2001). The former UK Prime Minister himself endorsed the cause, claiming that there is "no bigger long-term question facing the global community" than climate change (BBC News Online, 2004b).

If we turn to the issue of nuclear power and its contribution to energy production, no nuclear reactors have been built or ordered in the UK since construction of the Sizewell B pressurized water reactor, approved in 1985. The UK's existing stock of nuclear plants provided 22 percent of electricity supply in 2004 (World Nuclear Association, 2004), which, it has been estimated, reduces national carbon emissions by between 7 and 14 percent (DTI, 2003). Plans for future decommissioning as plants reach the end of their life mean that by 2020 total nuclear capacity will have reduced by around three quarters (POST, 2003). All of the first generation "Magnox" reactors (11 in total) are due to be closed by 2010 . The seven advanced gas-cooled reactors are scheduled to close between 2008 and 2023, and the Sizewell B pressurized water reactor will close around 2035 (POST, 2003). This closure program means that the significant contribution currently made by nuclear power to meeting national electricity demand will need to be met either by a switch to other forms of generation or by the contribution of a new generation of nuclear reactors.

In 1994, the government's "Review of the future prospects for nuclear power in the UK" examined the economic and commercial viability of new nuclear power stations. It took the view that circumstances did not warrant public sector support for a new nuclear power station-which it argued would constitute a significant intervention in the electricity market (DTI, 2003). Given the start-up, regulatory and decommissioning costs involved, it remains the case that the construction of new nuclear generation capacity is unlikely to be privately financed without government support (Wilson, 2005) and the nuclear industry and its supporters are lobbying government to create a market for nuclear power by ensuring the long-term stability of electricity prices (BNIF, 2001; Loughhead, 2005; see also Leake and Box, 2005).

Crucial to the account we develop in this paper is the linkage between climate change mitigation and securing sustainable energy futures. In this light, we argue that the UK is currently witnessing a new framing of nuclear power as "sustainable energy" and which presents the construction of new nuclear powered electricity (referred to as "new nuclear build") as essential to future energy policy and specifically delivering climate change mitigation. The notion of "framing" connotes "the perceptual lenses, worldviews or underlying assumptions that guide communal interpretation and definition of particular issues" (Miller, 2000: 212)_for instance identifying a problem or articulating a proposed solution to that problem. Importantly, framing offers a conceptual language for understanding how policy domains are defined and rendered manageable, that can accommodate both continuity and change (Jasanoff, 2005).

The framing of environmental and other public policy problems has become an increasingly prominent area of analytical inquiry in the social sciences (Miller, 2000; Jasanoff, 2005; Hajer, 1995; Schön and Rein, 1994; Benford and Snow, 2000; Ward et al., 2004; Gamson and Modigliani, 1989). However, relatively little attention has been paid to the dynamic processes by which particular environmental frames emerge, change (reframing), acquire credibility and are stabilized or backgrounded in particular contexts (Miller, 2000). It is the dynamic processes of reframing-frame changes that can not only influence how societies come to understand risk and to view appropriate policy responses but also open up new lines of critique for opponents - that underpin our approach to analyzing the social 
resonance of recent political rhetoric around new nuclear build and climate change mitigation (Schön and Rein, 1994).

The point we make here is that expansion of the nuclear power sector is increasingly being constructed, by industrial actors, scientists, a range of senior politicians and advisors to government within a prognostic policy frame-in other words it is being reframed as a solution to the problem of climate change. This is a shift in the framing of nuclear power which could have an impact on social "acceptability"-particularly at the level of citizen views - an issue widely recognized as critical to any decision about new nuclear build (Loughhead, 2005; see also BNIF, 2001). As David King, Chief Scientific Advisor (CSA) to the government, recently remarked, "I don't see any government being prepared to go down a route on an issue like this [new build] without taking the public with them" (quoted in McCarthy, 2005). The central (empirical and theoretical) problematic we address in this paper is therefore how citizens may respond to this particular reframing of policy. In doing so, we are concerned less with the frames citizens use for interpreting environmental problems - and rather more with their responses to the framing processes of other (institutional) actors (see also Miller, 2000). Our account draws on a study of public views of climate change and radioactive waste to explore how UK citizens might interpret and make sense of a shift in political rhetoric around energy policy, which links nuclear power to meeting sustainability objectives.

We begin the discussion with an overview of the emergence of a political reframing of "new nuclear build" as a route to delivering greenhouse gas reductions-which, in general terms, presents a risk trade-off between radioactive waste and climate change. Following on, we describe the research design and the datasets upon which the paper is based. In the main analysis, we integrate the quantitative and qualitative findings of a comparative risk perception study to identify key differences (and similarities) in how people make sense of or frame radioactive waste and climate change and the institutions responsible for managing these risks. By drawing upon some preliminary data where people directly engaged with the risk-risk trade-off, we consider the social resonance of this reframing as well as the more problematic features of mobilizing such a policy discourse. In the concluding section of the paper, we reflect on the societal implications of the emerging policy discourse of new nuclear build as a means of delivering climate change mitigation and set an agenda for future research regarding the (re)framing of the nuclear energy debate in the UK and beyond.

\section{Nuclear power and climate change mitigation}

The vexed issue of how to address the risks posed by climate change has spawned international negotiations, domestic strategies and public concern through the 1990s (Bulkeley, 2001). This debate is set to become even more complex as negotiations are initiated on the second commitment period for the Kyoto Protocol. Climate change mitigation is intimately bound up with issues of energy supply and demand. In the UK context, the most recent government thinking on "energy" was set out in the 2003 Energy White Paper: intended to guide Britain towards a sustainable energy future, it sets a domestic "aspiration"-more ambitious than the targets agreed under Kyoto-to achieve a 60 percent reduction of UK carbon dioxide $\left(\mathrm{CO}_{2}\right)$ emissions by $2050^{1}$ (DTI et al., 2003), and a goal of 20 percent $\mathrm{CO}_{2}$ reductions by 2010. At present, the primary means proposed to achieve this objective is a combination of greatly increased energy efficiency and greater use of energy generated from renewable sources, supplemented by increased use of gas-fired power stations. Serious doubts have, however, been raised that the UK's $\mathrm{CO}_{2}$ domestic ambitions will be achieved solely through 
these means (Sustainable Development Commission, 2004; Royal Society and Royal Academy of Engineering, 1999; BBC News Online, 2005b HM Government, 2006). Changes in energy supply present another challenge to meeting these long-term targets. By the end of the decade, the UK's indigenous natural resources of oil and gas will be substantially depleted; nuclear power stations will be reaching the end of their life, while a number of older coal-fired stations are likely to be phased out by the 2020s (DTI et al., 2003). Furthermore, there are recognized difficulties in enacting behavioral changes that move society towards less energy-intensive lifestyles and implementing sustainable energy options. Bearing out some of these issues, former Prime Minister Tony Blair acknowledged that the UK is not expected to meet the 2010 target (BBC News Online, 2004a); a situation that greatly increases pressure on the government to find means to deliver significant GHG emission reductions. Indeed, in a recent move, which suggests an increasingly technocratic framing of climate change mitigation, Blair signaled his opposition to tackling the problem through encouraging lifestyle changes-arguing that no country is going to cut its growth or consumption (Hennessy and Langton, 2005).

Under these circumstances, nuclear power is increasingly being talked about as the "real green" alternative (Marshall, 2005; Wintour and Brown, 2004; see also Knight, 2003; Vidal, 2004). The threat of global warming has been seized upon by an industry eager to press home the environmental imperative of switching from fossil fuel to nuclear power (Marshall, 2005). John Ritch, Executive Director of the London-based World Nuclear Association, an advocacy group backed by the power supply companies, has warned of "an approaching critical point at which devastating climate change will become irreversible," claiming that "humankind cannot meet this challenge without a sharply expanded use of nuclear power" (Ritch, 2005; see also BNIF, 2002). Significantly, the industry has mobilized a number of other framing discourses (strategically or more tacitly) to resonate with or enroll new adherents. Warnings of Britain's increasingly desperate energy outlook and the impending "energy gap"' have effected a change in the mood of major corporations towards nuclear power (Leake and Box, 2005; BBC News Online, 2005c; Milner, 2005). The political lobbying campaign spearheaded by the Nuclear Industry Association (the trade alliance for British nuclear companies), in the lead up to the 2005 general election, was carefully designed to focus on the shortcomings of the other energy alternatives-without completely dismissing them (Leake and Box, 2005; BNIF, 2002). Rather the lobbyists advocate a diversified supply capacity - with a revived nuclear industry at its heart (Leake and Box, 2005; BNIF, 2002).

There are as yet no plans to replace nuclear power stations that have reached the end of their life. The government's position as stated in the Energy White Paper is effectively one of "not now, but not never" (DTI et al., 2003). Although acknowledging that the economics and problems of waste disposal make nuclear power impractical, the document states that future nuclear build may be necessary to meet the nation's carbon targets. As this conclusion suggests, the policy position is far from secure and there is mounting pressure coming from some senior politicians, scientists and advisors to reconsider the option of nuclear power. This is well illustrated in the response of the then Energy Minister Brian Wilson, a keen supporter of the nuclear option, to the cautious position adopted in the White Paper; "I think the debate is moving in the direction of recognizing nuclear power as an essential part of a low carbon energy mix" (Jameson, 2004; Wilson, 2004). Sir Crispin Tickell, formerly the UK ambassador to the United Nations, has gone further, accusing British politicians of failing to give a lead on nuclear energy (Kirby, 2004). Indeed, a MORI survey found that 58 percent of Members of Parliament wanted to see nuclear energy as a major contributor to energy supplies in the future, with a massive 81 percent actually believing it will be a major contributor (Knight, 2003). 
The reframing of new nuclear build as a means of tackling climate change has also received widespread endorsement within the scientific establishment (see Leake and Box, 2005). For instance, a recent report ("How to Plug the Energy Gap") co-sponsored by the Royal Society of Chemistry, the Institute of Physics, the Energy Institute, the Institution of Electrical Engineers and the Institution of Civil Engineers, publicized the result of a multidisciplinary consensus meeting to consider the challenges that the UK faces in ensuring a secure, affordable and environmentally acceptable supply of energy in the period to 2050. The report argues that reducing carbon emissions will require action on different aspects of the energy system, but within this strategy identifies new nuclear build as almost certainly needed (see Loughhead, 2005). In the words of the author: "Throw away the emission targets and there is no problem. But keep them and the nuclear option has to be the way" (Loughhead, quoted in Lovell, 2005). Lord May, President of the Royal Society and former Chief Scientific Advisor to the government, made a similar point, arguing that "it will be difficult for Britain to lead the way on climate change in the mid-term future without building new nuclear power stations" (May, 2004). Sir John Houghton, former head of the Meteorological Office and the former director of the UN's Intergovernmental Panel on Climate Change, has added his voice to the call for new nuclear power stations. We therefore appear to be seeing an emerging political rhetoric around nuclear energy which ties new build to climate change mitigation and meeting emission reduction targets.

This reframing of nuclear policy has increasingly powerful advocates at the heart of government. Prominent advisors to the former Department of Trade and Industry (DTI) on energy strategy have recently argued that nuclear power will need to provide half of Britain's electricity needs if the government is to have any hope of meeting its Kyoto targets for reducing greenhouse gases (Jameson, 2004; see also House of Commons Trade and Industry Committee, 1998). David King (the CSA) has notably reframed the issue in terms of whether renewable energy can replace nuclear in meeting energy needs: "If it can't ... I would image that one further generation of nuclear power stations would be all that would be required" (quoted in McCarthy, 2005). It is a framing within government (like industry) which rests on the necessity of bridging the "energy gap" and simultaneously delivering on the UK's demanding global warming targets (see also Wilson, 2005). Tony Blair himself has stated that the government does "not rule out the possibility that at some point in the future new nuclear build might be necessary if we are to meet our carbon targets" (Blair, 2004). Indeed, the former Prime Minister's announcement of a government review of energy options has been received by some media commentators as paving the way for new nuclear build (Kirup, 2005; Morgan, 2005a).

Looking beyond the boundaries of the UK, there are also indications that the European Commission will leave the nuclear option open as a positive contribution towards the mitigation of climate change (Gow, 2004). Even some environmentalists, many traditionally hostile to nuclear power, have begun to question old assumptions or frames (Vidal, 2004). Ecologist James Lovelock, heavily linked with deep green thinking, has publicly argued that nuclear, for now, is the only workable alternative: "I'm absolutely sure that if we-by which I mean civilization-are going to get through this century without some greenhouse disaster, we've just got to use nuclear on a grand scale. Renewables simply can't do it in time" (quoted in Black, 2003; see also Bullock, 2005). Similarly, the directors of the UK's Centre for Alternative Technology have argued that "the worst possible nuclear disasters are not as bad as the worst possible climate change disasters" (an explicit assertion of the risk-risk trade-off), and suggested "a modest revival of nuclear energy in sites where there are already nuclear installations ... to sell the idea to the sceptics" (Monbiot, 2004; see also Vidal, 2004). 
It is, however, important to stress that the political reframing of new nuclear build in the UK cannot be described as a stable or durable alliance of actors; its logic and efficacy being subject to ongoing counter-framing, both internal and external to government. The media have widely reported contestation at the highest levels of the Blair administration (Wintour and Milner, 2005; Hall, 2005; Woolf, 2005; Charter, 2005; Morgan, 2005b). Environmental advocacy groups such as Greenpeace and Friends of the Earth remain implacably opposed to the notion that further nuclear build could be good for the environment. They counter with claims that stress the poor case for new build on environmental (climate change) and economic grounds, and challenge the pro-nuclear argument that renewable energy cannot (in and of itself) deliver the necessary reduction in carbon emissions (Greenpeace, 2005; Roche, 2005; FoE, 2004). The dominant counter-frame from the environmental non-governmental organization (NGO) sector rests on the issue of safety (accident/terrorist risks and the production of dangerous nuclear waste): "nuclear power atoms are no different to the atoms used in nuclear weapons and dirty bombs. As terrorist targets, nuclear power stations are expensive, polluting sitting ducks_-static time bombs" (Greenpeace, 2005). The picture then is still a dynamic one with a range of (counter) frames being mobilized within and between protagonist sectors engaged in the debate.

In the light of the emergent political rhetoric around the nuclear option, the purpose of our account is to draw on a study of citizen views of climate change and radioactive waste (the two principal environmental hazards in what amounts to a risk trade-off around energy and sustainability) to begin to unpack the likely social resonance of such an energy policy reframing. Whilst there are limitations to the conclusions that we can draw, since the data do not directly engage with current political debate around new nuclear build, we believe that collectively they provide a strong preliminary grounding for researching the citizen responses to a political reframing of expansion in the nuclear power sector.

\section{Research methods}

The main analysis draws on two sources of data, a nationally representative survey and four "paired" focus groups (where participants met twice); both collected in 2002 as part of a larger comparative study of public understandings of a number of different risk issues. These data were collected at a time before new nuclear build had become strongly linked to climate change mitigation in political or more widely media debate. In doing so, our objective was not to simply gather citizen responses to an already circulating political reframing but rather to explore the dynamic discursive practices by which people made sense of and negotiated what for most was a new way of thinking about the two environmental problems. The survey, which explored citizen attitudes towards five risk cases, was professionally administered by the opinion poll firm MORI. The total sample of 1,547 respondents, drawn from across Britain, comprised five separate representative subsamples of approximately 300 responses. Respondents in each of the sub-samples were asked a series of questions by face to face interview, each focusing on just one risk case: climate change, radioactive waste, genetically modified food, radiation from mobile phones or genetic testing (Poortinga and Pidgeon, 2003b). In this paper we report only on the results that relate to climate change and radioactive waste.

As a complement to the survey, four "paired" focus groups were undertaken between September and December 2002, in four locations across England: Cromer and Norwich in the East; Heysham and Liverpool in the North-West of the country. Each group comprised two, 2-hour discussions linked by the common theme of energy and the environment. The first 
meeting addressed climate change whilst the second looked at radioactive waste. The core themes covered by both meetings were, in order: the imagery and associations linked to each issue; the (distribution of) costs and benefits; knowledge and uncertainty relating to the problems and solutions as well as issues relating to governance and citizenship. The second meeting did, however, open with the topic of nuclear power (as one possible option for addressing climate change) and close with a short third phase where people were encouraged to reflect upon the risk-risk trade-off. Altogether 32 people participated, 18 men and 14 women, with mixed socio-demographic characteristics; recruitment, using professional recruiters, ${ }^{3}$ was designed to ensure a broad mix of social backgrounds rather than a representative sample. All discussions were tape-recorded and transcribed in full. The transcripts were coded using the NVivo software package-with nodes and links identified and refined through an interaction between emergent themes and the findings of previous risk perception research. Verbatim quotations have been selected to illustrate sentiments or understandings expressed. In all cases names have been changed to protect participant anonymity. Whilst there are inevitable constraints to how far we can genuinely triangulate the two datasets, we feel that they offer complementary perspectives on citizen understandings of climate change and radioactive waste. In the following section we bring together the two datasets to consider citizen responses to the risks posed by climate change and radioactive waste.

\section{Data analysis}

\section{The characteristics of risk}

In considering how people made sense of or actively framed radioactive waste and climate change risks, it is useful to first situate our account within the broader context of the UK's experience of science and environmental risks. In the wake of the bovine spongiform encephalopathy (BSE or "mad cow disease") crisis, severe criticism of government handling of the foot and mouth disease epidemic in 2001, and controversy over the risks, benefits and social consequences of genetically modified crops and foods (House of Lords Select Committee on Science and Technology, 1999; Phillips et al., 2000) the UK has witnessed a growing public distrust of authority and expertise in relation to science based policy issues (Jasanoff, 2005). We might also add to this list the collapse in 1997 of the technocratic strategy pursued for almost two decades by government and industry to establish a deep repository program for managing radioactive wastes. The secrecy and arrogance that marked decision-making are widely cited reasons for the deepening mood of public opposition towards nuclear technology that ultimately led to policy failure (Hetherington, 1998 [1997]; House of Lords Select Committee on Science and Technology, 1999). Events during the 1990s crystallized a growing unrest within society, as people who felt excluded from scientific and technical decisions significantly affecting their lives began to question the ends of government and the ends of technology (Jasanoff, 2003, 2005). This collective experience of risk management we anticipated would have some mediating role on citizens' views about climate change and radioactive waste; in particular on the associated issues of trust, competence and accountability and the attempts to reframe new nuclear build in terms of a necessary risk-risk trade-off with climate change.

It is worth stating at the outset that our analysis found that the ways in which people reasoned about the two issues had both similarities and differences. In the survey, respondents were asked to evaluate climate change and radioactive waste on various dimensions (see Table 1, also Poortinga and Pidgeon, 2003b). Evaluations were chosen from a large number of psychometric characteristics (see e.g. Slovic, 2000); respondents were asked whether the 
Table 1. Evaluation of climate change (CC) and radioactive waste (RW): percentage of respondents who agreed / strongly agreed with the psychometric statements.

\begin{tabular}{|c|c|c|c|}
\hline \multirow[b]{2}{*}{ Psychometric characteristics } & \multicolumn{2}{|c|}{$\begin{array}{l}\text { Percentage respondents who } \\
\text { agree / strongly agree }\end{array}$} & \multirow[b]{2}{*}{$\chi^{2}(1)$} \\
\hline & $\mathrm{CC}$ & RW & \\
\hline $\mathrm{CC} / \mathrm{RW}$ has unknown consequences & 81 & 78 & 0.88 (n.s.) \\
\hline $\mathrm{CC} / \mathrm{RW}$ poses risks to future generations & 85 & 86 & 0.29 (n.s.) \\
\hline $\begin{array}{l}\text { I feel able to control any risks to } \\
\text { myself associated with } \mathrm{CC} / \mathrm{RW}\end{array}$ & 17 & 12 & 3.61 (n.s.) \\
\hline $\begin{array}{l}\text { The risks of CC/RW are unfair because } \\
\text { they fall unevenly on particular groups } \\
\text { in British society }\end{array}$ & 26 & 46 & $22.02,(\mathrm{p}<.001)$ \\
\hline The idea of CC/RW fills me with dread & 35 & 50 & $11.26,(\mathrm{p}<.001)$ \\
\hline
\end{tabular}

n.s., not significant

Source: UEA/MORI Risk Survey 2002 (CC: $N=321$; RW: $N=306)$.

risk had "unknown consequences," posed "risks to future generations," filled them with "dread," and whether they thought that the risks were "unfair because [they] fall unevenly on particular groups in British society." Climate change and radioactive waste were negatively evaluated (both issues were equally associated with unknown consequences, risks to future generations and low levels of personal control). Radioactive waste, however, was associated with a greater level of dread $\left(\chi^{2}(1)=11.26, p<.001\right)$ and an unfair distribution of risks $\left(\chi^{2}(1)=22.02, p<.001\right)$ (see Table 1). These findings seem to converge with the existing (psychometric) research literature, which identifies radioactive waste as a unique risk case. More so than other risk cases, radioactive waste is dreaded and seen as having a high potential for disaster (see e.g. Slovic, 2000; Marris et al., 1998). On an overall measure of concern, our survey respondents were more concerned about radioactive waste: 28 percent were "very concerned" about climate change and 39 percent were "very concerned" about radioactive waste $\left(\chi^{2}(1)=7.54, p<.01\right)$. Similarly, radioactive waste was far less acceptable to people overall with 63 percent saying it was very or fairly unacceptable compared with climate change where only 44 percent said it was very or fairly unacceptable $\left(\chi^{2}(1)=22.52, p<.001\right)$.

The focus group data help us to account for these quantitative differences. People rarely used the language of dread and fear in talking about climate change-with consequences unknown and remote in time and space (see also Lorenzoni et al., 2006). Whilst participants in the groups offered a range of possible effects (such as ice caps melting, sea level rises), these were disconnected or detached from everyday life: they would happen somewhere else and to someone else.

Paula: The ice caps melting and the sea levels rising, parts of America will disappear.

Jack: We'll lose ... the Antarctic will start to disappear won't it? There will be a lot of lake-land villages [that] will start to disappear. ...

Sue: I suppose everyone will have different locations to live in won't they? They'll just learn to move around and adapt. (Heysham, climate change)

Importantly, climate change lacked a deeply affective cultural imagery-which had the effect of keeping risks materially and culturally remote. Other research has similarly demonstrated that against a background of widespread citizen concern climate change lacks issue salience (e.g. Ungar, 2000; Bord et al., 2000; Lorenzoni and Pidgeon, 2006). In other words, when risks are 
perceived to be removed from everyday life, dangers become more distant in space and time, and personal concern and action are seen to be increasingly futile (Bulkeley, 2000; Hinchliffe, 1996).

By contrast, the discussions all revealed a profoundly negative set of responses to the idea of radioactive waste, and in this way support the findings of the national survey. People's immediate reactions to the issue, across all of the groups, referenced feelings of fear, and images of death, danger and catastrophe (see also Slovic et al., 1991):

Caroline: It just spells danger to me, that's probably the most obvious thing that comes to me-in the disposal of it and the storage of it and if it gets into the wrong hands-it all spells disaster unfortunately. (Liverpool, radioactive waste)

Things nuclear had what one person termed a "dark side" (Liverpool, radioactive waste) and were strongly associated with concerns and fears linked with the military and warfare:

Fiona: I think a lot of the problem with the nuclear power is ... firstly like the fear that people have of it in terms of how it can be used in war and bombs and that sort of thing. But that is a real, real off put for people. (Norwich, radioactive waste)

For many, radioactive waste was also intimately connected to a rich cultural repertoire of images associated with the history of nuclear technology (primarily in the UK), centering on errors and concerns about institutional control, secrecy and competence. These images are deeply rooted in social and cultural memory, a collective consciousness that dates back to the beginning of the twentieth century (Weart, 1988; Erikson et al., 1994; Hunt and Simmons, 2001; Flynn, 2003).

Paula: It sounds to me like a bunch of people decided to start out this nuclear power thing and it's like, well it's like the Homer Simpson thing isn't it? You are putting it in the hands of these people and they have no idea what the consequences of it are-they are not even gonna be around. And yet we are playing around with it like you know it's jelly and ice cream or something. (Heysham, radioactive waste)

Major nuclear incidents such as Three Mile Island (USA 1979), the 1957 fire at Windscale/ Sellafield, and the Chernobyl accident in 1986, are crucial to understanding people's concern about the nuclear industry. Indeed, participants in all focus groups made the link between radioactive waste and the Chernobyl accident-an association that highlights the deep and vivid penetration of Chernobyl into the public psyche as a global disaster (Zonabend, 1993; Hunt and Simmons, 2001; Boholm, 1998). A deeply affective imagery associated with the threat of international terrorism was similarly mobilized to articulate the catastrophic potential of nuclear wastes. A recent UK MORI poll adds to the picturerevealing a widespread view that nuclear plants are vulnerable to terrorist attack (76 percent of respondents), with over half of those polled thinking that atomic energy causes dangerous pollution (Murray-Watson, 2005a). In these ways, nuclear waste was constructed as an immediate threat. It presented a disaster that could and did affect local places and could occur at any time. It is a set of concerns which, as the following remark illustrates, resonate with the dominant counter-frame mobilized by many environmental NGOs against new nuclear build:

Bob: These environmental people in my view have got a point. If you listen to the radio or the television this morning there was an Irish minister and he was saying close to Sellafield ... when it was designed and built it wasn't envisaged that an aircraft would plough into it—could plough into it—and what a disaster that would be. (Cromer, radioactive waste) 
Table 2. Perceived benefits and risks of climate change and radioactive waste: percentage of respondents stating medium to high benefits / risks for themselves / society.

\begin{tabular}{lccccc}
\hline & \multicolumn{2}{c}{ Medium-High Benefits } & & \multicolumn{2}{c}{ Medium-High Risks } \\
\cline { 2 - 3 } \cline { 5 - 6 } & Personally & To society & & Personally & To society \\
\hline Climate change & 18 & 20 & 46 & 50 \\
Radioactive waste & 7 & 8 & 52 & 60 \\
\hline
\end{tabular}

Benefits personal $\chi^{2}(1)=22.76, \mathrm{p}<.001$; benefits society $\chi^{2}(1)=21.92, \mathrm{p}<.001$

Risks personal $\chi^{2}(1)=0.38$, n.s.; risks society $\chi^{2}(1)=3.65$, n.s.

Source: UEA/MORI Risk Survey 2002 (CC: $N=321$; RW: $N=306)$.

The importance of perceived risks and benefits is a recurring theme in the risk perception literature. In many cases, risky activities or technologies also have distinct benefits. It is generally assumed that judgments of risks and benefits are a major driver of people's responses to a specific activity or technology (see e.g. Slovic, 2000). Some studies have reported a negative relationship between perceived risks and perceived benefits (e.g. Alhakami and Slovic, 1994), which may reflect a general (affective) evaluation of a hazard (see e.g. Slovic et al., 2004). In the present study, respondents were asked to assess the risks to British society as a whole as well as the risks to themselves for the two issues. Likewise, they were asked to assess the benefits for British society as well as the benefits for themselves. The survey results show that climate change is seen as less risky than radioactive waste but more beneficial (see Table 2); again suggesting that radioactive waste was evaluated more negatively overall than climate change. A similar pattern emerges from the survey responses relating climate change and radioactive waste to their causes, in terms of the benefits of energy production and consumption. Activities that lead to changes in the climate (e.g. car use, factories, and energy use generally) were perceived by about a third of survey respondents to be beneficial for individuals personally and for society as a whole (30 percent and 31 percent, respectively, of respondents associated these activities with medium to very high benefits). The activities that generate radioactive waste, such as nuclear power production, were by 28 percent seen as beneficial for society and by 22 percent beneficial for individuals personally. While the differences for the benefits for society were not significant $\left(\chi^{2}(1)=1.35\right.$, n.s.), activities leading to climate change were seen as more beneficial for individuals personally than activities that generate radioactive waste $\left(\chi^{2}(1)=6.46, p<.05\right)$.

The structure of the focus groups - which explicitly linked both problems to energy production and consumption-allowed people to develop connections between cause and effect. What was noticeable when people talked about climate change were the links made to a strong cultural imagery which referenced not the risks but the benefits associated with energy consuming technologies (transport, heating and other everyday products). It was an association that was largely absent in discussing radioactive waste. The secondary consequences of energy production, in terms of pollution and climatic alterations, were constructed as unavoidable — to enable the conveniences of modern living:

Caroline: [B]ut what's important? I mean, I think we've all said it but what's more important to the government is people stay in jobs and we have industry and the country keeps ticking over-or we get warmer summers or warmer winters? What's more important to them? What's more important to us if we're all very, very honest? (Liverpool, radioactive waste)

McDaniels et al. (1996) similarly observed that sources of global change processes are viewed quite differently to the consequences. The authors suggest that this might be due to 
greater familiarity and reliance on these everyday "causal" activities. This familiarity, they add, leads people to be more knowledgeable about these activities and to consider them (and their consequences) as an acceptable and necessary part of everyday life.

Taken together, these findings point to some important differences in risk characteristics and how people were framing the two problems. Climate change was largely seen as an unknown danger that lacked a deep historical or cultural embedding, and as such posed a remote and distant threat. Yet, the "benefits" people associated with the climate change issue (very clearly constructed in terms of energy producing and consuming technologies) were talked about as all too immediate and necessary. By contrast, radioactive waste emerges as an issue linked to images and symbols of dread and unfairness, connected with a technology that is more clearly identified with risks and harm than benefits. On purely cost and benefit terms, this might lead us to anticipate that citizens would generally reject a reframing of nuclear power as a solution to the problem of climate change. However, in understanding differences in how people made sense of the two problems (as side-effects of energy production/consumption) we also need to look towards citizen views of institutional actors involved in regulating risk-specifically government and science.

\section{Trust, competence and accountability}

In the field of risk research, there has been a growing recognition that trust in (risk) regulators is an important factor in shaping citizen reactions to risk (e.g. Renn and Levine, 1991; Earle and Cvetkovich, 1995; Johnson, 1999; Slovic, 2000; Poortinga and Pidgeon, 2003a, 2005) and, we would suggest, to the policy (re)framings mobilized by these same institutional actors. A range of factors have been identified as influencing these trust relations, which Johnson (1999) summarizes under the themes of competence, care and consensual values. These categories, which were central components in our questionnaire design, reflect the extent to which an institution or person is considered as having the expertise and capability to manage risks, is seen as being open, honest and acting in the public interest, and is perceived to hold the same values as the person making the trust judgment.

Table 3. Trust in sources to tell the truth about climate change (CC) and radioactive waste (RW): percentage of respondents who trusted the following organizations a little / a lot.

\begin{tabular}{|c|c|c|c|}
\hline \multirow[b]{2}{*}{ Trust statements } & \multicolumn{2}{|c|}{$\begin{array}{l}\text { Percentage of respondents who } \\
\text { trusted a little / trusted a lot }\end{array}$} & \multirow[b]{2}{*}{$\chi^{2}(1)$} \\
\hline & $\mathrm{CC}$ & RW & \\
\hline Environmental organizations & 77 & 75 & 0.24 (n.s.) \\
\hline $\begin{array}{l}\text { Scientists working for } \\
\text { environmental groups }\end{array}$ & 70 & 69 & 0.38 (n.s.) \\
\hline Scientists working for universities & 70 & 67 & 0.88 (n.s.) \\
\hline Scientists working for government & 42 & 48 & 2.41 (n.s.) \\
\hline Local authorities & 38 & 50 & $8.51(\mathrm{p}<.01)$ \\
\hline $\begin{array}{l}\text { Scientist working for nuclear/ } \\
\text { energy industry }\end{array}$ & 31 & 36 & 2.09 (n.s.) \\
\hline The national government & 31 & 35 & 0.91 (n.s.) \\
\hline European Union & 29 & 35 & 2.45 (n.s.) \\
\hline Car companies & 21 & $\mathrm{n} / \mathrm{a}$ & - \\
\hline Oil companies & 19 & $\mathrm{n} / \mathrm{a}$ & - \\
\hline Ministry of Defence & $\mathrm{n} / \mathrm{a}$ & 41 & - \\
\hline Nuclear Industry & $\mathrm{n} / \mathrm{a}$ & 30 & - \\
\hline
\end{tabular}

n/a, not applicable, n.s., not significant

Source: UEA/MORI Risk Survey 2002 (CC: $N=321$; RW: $N=306)$. 
In the survey, respondents were asked to indicate the extent to which they trusted various sources to tell them the truth about climate change and radioactive waste (see Table 3). Noticeable in the results are the similarities across the two issue contexts. In both cases we see a high degree of trust associated with environmental organizations and with scientists working for universities and working for environmental groups. Levels of trust were much lower for national government, scientists working for the nuclear industry and the Ministry of Defence, with stronger distrust expressed towards car companies and oil companies. The consistency of these findings does suggest culturally specific views that relate not necessarily to the issues per se but to more general concerns about the politics of environmental risk governance. However, these results do not indicate complete and unambiguous skepticism of politics and business. Roughly one third of respondents claimed to trust (a little/a lot) national government across both issues and the nuclear industry in relation to radioactive waste, with around one fifth stating that they trusted (a little/a lot) oil and car companies with respect to the climate change issue.

The focus group material provides a different perspective on the issue of trust and sheds light on how people related to different sources of expertise-both science and politics. In general terms participants talked about science as intrinsically a good thing-it was progressive and an important force for human improvement. Indeed, across the groups participants often expressed the view that the unique and specialist capacities of science or scientists could and would produce solutions to the problems created by radioactive waste and climate change. However, rather than absolute confidence, these comments reveal a hope that science will deliver answers-even a sense of dependency-reflecting an apparently technocratic framing of the solution:

Paula: These scientists, everyone should be responsible for it. If they're so amazingly you know, um, intelligent and everything ... then surely they should be able to come up with something [a solution to climate change]. (Heysham, climate change)

People implicitly or explicitly referred to the unique powers of science in terms of its inaccessibility, often prefacing comments with statements of their own sense of ignorance (e.g. "I'm just a lay person," "I'm not a scientist," "I don't know"). This exclusivity was manifest in a privileging of the competences of science in contrast to a personal absence of knowledge-most apparent with radioactive waste. Rather than reading such remarks as merely displays of knowledge deficit, we might also recognize them as an active fashioning of relations of dependency on and cooperation with (or challenges to) science (Michael, 1996). Indeed reflecting a relation of cooperation (in terms of a division of labor) it was argued by many participants that science in an abstract and neutral sense (corresponding to the university scientists in the survey findings) was best placed to make decisions about the management of radioactive wastes and to a lesser degree climate change: it was their job.

Valerie: So it's no use debating this is it, because it's already there, it's already happened. So hopefully all of us through our taxes ... we pay the government to pay scientists to do the best with it for the good of everybody and that's all that I hope we can do. There's no use having discussions about it. (Liverpool, radioactive waste)

The implication one could draw here is that if policy, framed as a pure science question, were to identify nuclear new build as an appropriate mechanism for addressing climate change this might be broadly acceptable to the wider citizenry. However, as we demonstrate in the following analysis, the picture becomes more complex when we consider people's evaluations of government (decision-making) and as such the interface between science, politics and industry. 
Table 4. Evaluation of Government with regard to climate change (CC) and radioactive waste (RW): percentage of respondents who agreed / strongly agreed with the statements.

\begin{tabular}{|c|c|c|c|}
\hline \multirow[b]{2}{*}{ Evaluation of government statements } & \multicolumn{2}{|c|}{$\begin{array}{l}\text { Percentage of respondents who } \\
\text { agree/strongly agree }\end{array}$} & \multirow[b]{2}{*}{$\chi^{2}(1)$} \\
\hline & $\mathrm{CC}$ & RW & \\
\hline \multicolumn{4}{|l|}{ Competence } \\
\hline $\begin{array}{l}\text { The government is doing a good job } \\
\text { with regard to CC/RW }\end{array}$ & 13 & 12 & 0.08 (n.s.) \\
\hline $\begin{array}{l}\text { The government is competent enough } \\
\text { to deal with CC/RW }\end{array}$ & 22 & 22 & 0.06 (n.s.) \\
\hline $\begin{array}{l}\text { The government has the necessary skilled } \\
\text { people to carry out its job with regard to CC/RW }\end{array}$ & 36 & 40 & 0.69 (n.s.) \\
\hline \multicolumn{4}{|l|}{ Credibility } \\
\hline $\begin{array}{l}\text { The government distorts facts in its } \\
\text { favour regarding CC/RW }\end{array}$ & 55 & 59 & 0.17 (n.s.) \\
\hline \multicolumn{4}{|l|}{ Reliability } \\
\hline $\begin{array}{l}\text { The government changes policies regarding } \\
\text { CC/RW without good reasons }\end{array}$ & 46 & 40 & $6.04(\mathrm{p}<.05)$ \\
\hline $\begin{array}{l}\text { The government is too influenced by } \\
\text { industry regarding } \mathrm{CC} / \mathrm{RW}\end{array}$ & 57 & 53 & 3.26 (n.s.) \\
\hline \multicolumn{4}{|l|}{ Care } \\
\hline $\begin{array}{l}\text { The government is acting in the public } \\
\text { interest with regard to CC/RW }\end{array}$ & 23 & 22 & 0.29 (n.s.) \\
\hline $\begin{array}{l}\text { The government listens to concerns about } \\
\text { CC/RW raised by the public }\end{array}$ & 21 & 23 & 0.51 (n.s.) \\
\hline $\begin{array}{l}\text { The government listens to what ordinary } \\
\text { people think about CC/RW }\end{array}$ & 14 & 13 & 0.07 (n.s.) \\
\hline \multicolumn{4}{|l|}{ Fairness } \\
\hline $\begin{array}{l}\text { I feel that the way the government makes } \\
\text { decisions about CC/RW is fair }\end{array}$ & 11 & 13 & 0.76 (n.s.) \\
\hline \multicolumn{4}{|l|}{ Openness } \\
\hline $\begin{array}{l}\text { The government provides all relevant } \\
\text { information about CC/RW to the public }\end{array}$ & 7 & 6 & 0.65 (n.s.) \\
\hline
\end{tabular}

n.s., not significant.

Source: UEA/MORI Risk Survey 2002 (CC: $N=321$; RW: $N=306)$.

In the survey, respondents were also asked to evaluate the government in further detail (Table 4). Once again, what is noticeable across the two issue domains are the broadly similar patterns of institutional evaluation (cf. Poortinga and Pidgeon, 2003a), suggesting that people evaluate government policy as a whole rather than specific governmental policy or decisions with respect to the two risk cases (Poortinga and Pidgeon, 2003a). Only 22 percent of respondents felt the government was competent enough to deal with climate change and radioactive waste. The survey shows a higher level of agreement with the statement that "the government has the necessary skilled people to carry out its job" with regard to climate change/radioactive waste. The issue of skepticism and distrust arises over the translation of this knowledge or skill base into policy.

For both issues there was a consistent belief that government was neither reliable nor credible. This was reflected in strong agreement with the statement "the government is too influenced by industry" regarding climate change (57 percent) and radioactive waste ( 53 percent). A similar pattern of response to the statement "the government distorts facts in its favour" can be observed (55 percent and 59 percent for climate change and radioactive waste respectively). With regards to care, views were more ambivalent with roughly one fifth of 
respondents agreeing and two fifths disagreeing with the statement "the government is acting in the public interest" with regards to climate change and radioactive waste. The data reveal a similar level of skepticism on the issue of how far the government listens to the concerns raised by citizens. Only about one in five respondents felt that the government listens to concerns raised by the public about climate change and radioactive waste ( 21 percent and 23 percent, respectively). Finally, in the survey data we see a high degree of skepticism expressed in response to the statement "the government provides all relevant information about climate change/radioactive waste to the public" with 7 percent and 6 percent agreement respectively (62 percent and 66 percent disagreement).

Together, these results point to a perceived failure of openness on the part of government and indicate that the majority of (but by no means all) people are skeptical about the government motivations underpinning policy which are seen to be bound up with other vested interests-views that arguably cite the closed decision-making structures that have traditionally shaped the UK's experience in the governance of science and technology.

Returning to the focus group material, we can find support for these conclusions. In particular they contain only limited overt criticism of the competence of government in terms of access to necessary skills. However, competence (particularly of science) and the role(s) of government are compromised where doubts exist about the interests and motivations of the state which are seen to be acting against the civic good. These doubts are consistent with what Freudenburg (1993) refers to as "institutional recreancy," that is the perceived failure of actors or systems to carry out responsibilities as expected. So, whilst expectations of social responsibility are directed towards government (and others) to make decisions and legislate to address climate change and manage radioactive waste, there is simultaneously a lack of confidence that these duties will be fulfilled (see also Bickerstaff and Walker, 2002; Hinchliffe, 1996, 1997; Blake, 1999; Bulkeley, 2000; Harrison et al., 1996; Walls et al., 2004).

Consistent with the survey findings, participants talked of the vested interests and hidden agendas which they saw as compromising policy processes and undermining political rhetoric. Many emphasized the short-termism and partiality embedded within politics and its orientation towards establishing and retaining positions of power (see also Harrison et al., 1996):

Heather: We're going to have to be persuaded to do things like that the way I see it ... or very slowly change because as I said no government is going to make itself so unpopular by bringing in unpopular laws. No government [is] going to do it. I don't care who they are, Tories, Socialist, Communist whatever, I don't think they are going to [want to] be the ones who are unpopular. (Cromer, climate change)

For many respondents, the scientific claims made about climate change and radioactive waste detracted from the real issues, namely the funding of science by government and especially by industry. In other words, the findings of scientific research would be appropriated by particular industry and government actors to stress the uncertainty or apparent absence of risks (Michael, 1992). This argument was most forcefully made with regards to climate change, where science and policy were seen to be firmly bound up with "big business":

Sue: $[\mathrm{O}] \mathrm{r}$ the environment because they don't care I suppose. And like big polluters in America they want more and more don't they? So if you've got scientists coming from America saying, "Oh it's not that", I mean you just think ... They want ... it a bit more don't they? They're with the car industry on that one, you know. (Heysham, climate change)

Concerns about institutional secrecy were all too apparent and invariably linked to the persistence of vested interests. Issues of secrecy were most evident in conversation around 
nuclear power and waste management-heightening fears about risks that were perceived as being hidden (for reasons that were being kept from the citizenry). In this regard people often drew upon beliefs about cover-ups by the nuclear industry (especially relating to Britain's controversial Sellafield site) to back up their arguments. In relation to both issues then we see strong expressions of skepticism in policy processes that were judged to be heavily influenced by political self-interest - a cynicism that we might anticipate would influence citizen responses to industry, government or even scientific claims as to the (environmental) necessity or safety of new nuclear build. In the final section of this discussion we turn our attention to how people dealt with and made sense of the explicit climate change-nuclear power tradeoff or policy framing in the focus group discussions.

\section{The climate change mitigation-nuclear power risk-risk trade-off}

In the third phase of the focus groups, participants were asked to reflect on the trade-off between the risks associated with nuclear power ${ }^{4}$ and those associated with climate change (although such reflections also occurred at earlier points in the second meeting). It is important to reiterate at this point that responses to the risk-risk trade-off were not sought in the national survey. Overall, just two individuals of the 32 in the discussion groups, actively and wholeheartedly supported climate change mitigation through new nuclear build as an appropriate and acceptable policy position. A greater number (to varying degrees, the majority of participants) did, however, arrive at the conclusion, usually after debate, that there was little or no choice- that in effect pursuing the nuclear option was necessary or the lesser of two evils (see also Mukherjee, 2005). This discourse of what we might refer to as reluctant acceptance - a resignation verging on frustration that there was no avoiding some continued dependence on the nuclear sector-was a common response to the explicit reframing of new build in terms of climate change mitigation.

Jill: And we haven't a lot of choice have we at the moment, you see.

Sue: No choice, have we, so we are stuck now with it at the moment.

Jackie: No choice.

Sue: 'Cause we haven't got a choice or an alternative, that's all, not happy with it at all. (Heysham, risk-risk trade-off)

Beginning from individual and group positions on nuclear power that, as we have documented, were resolutely negative, there were observable shifts towards more mixed and open views about this issue when participants considered climate change. The question of whether such changes are lasting, or more fleeting adjustments to an altered situation, is perhaps beyond the scope of this paper. Nevertheless, the recurrence of such shifts does indicate that citizen attitudes to nuclear power are not necessarily, for most people, fixed. Indeed, what we see is arguably a degree of reflexivity, akin to a form of frame reflection (Schön and Rein, 1994), where prior views are interrogated in the light of new information or an alteration in how a particular problem and its solution are presented. For most, the result was a greater degree of ambivalence and uncertainty regarding earlier views about nuclear power. On this basis we might well reason that a policy discourse, framing new nuclear build in terms of climate change mitigation would lead people towards a position of reluctant acceptance (and in many cases a personal reframing of the new nuclear build issue). In the extract below, the shift in attitude is all too clear, with Heather actively reflecting back on her initial feelings (and position) towards radioactive waste and nuclear power after the issue of climate change mitigation had been discussed: 
Heather: I've never thought about it before until last night. And I didn't realize that nuclear, nuclear fuel, I'm so ignorant, you didn't get the emissions in the same way as you do the other ones. So, I suppose, yes [I would accept the trade-off]. (Cromer, risk-risk trade-off)

In the following two extracts from Sally, a participant in the Liverpool group, her initial response reveals an intense reaction against the waste issue and a rejection of the issue reframing: "I think I could cope with the climate change and coastal erosion couldn't you, but you couldn't cope with [nuclear] disasters, could you." Yet when Sally was specifically asked to consider nuclear power as a potential means of mitigating climate change in the latter part of the session, after further discussion had taken place, we see a personal reframing of the issue expressed in the form of a discourse of reluctant acceptance. She comments: "I suppose it's [expansion in nuclear power] a necessary evil really isn't it [laughs] in a way."

It is useful to set such findings in the context of broader trends in public opinion. As we noted earlier, not only has the issue of climate change received increasing government and media attention over the past decade but also proponents of nuclear power have been actively promoting their cause. Opinion poll data suggest that this may be having an effect on citizen views. A recent MORI survey (Jameson, 2005) for the Nuclear Industry Association appears to show, for the first time since 1999, a swing in favor of nuclear power. The poll found that 35 percent of the population said they felt favorable towards the nuclear industry and nuclear energy, compared to 2001 when the figure was 19 percent. Of course, such findings raise quite complex questions about the nature and basis of this apparent public support and shift in opinion. Here, we note the results simply for their correspondence to patterns that emerged in our focus group data.

However, we would not wish to suggest that all participants adopted (solely) these patterns of discourse or that the articulation of such views was merely as a response to the issue reframing. Indeed, as the quote below highlights, most people in the focus groups undoubtedly found this a deeply problematic trade-off to make and were not at all comfortable with what they saw as an overly simplistic either/or choice:

Mark: Yeah, you described this as the best option; I mean is it the best option? Or is it the only option? Or is it the best of a bad bunch, if you see what I mean ...

James: Is it a good option?

Mark: You know, having a head-on [collision] with a truck or a tree ... the best option is possibly the tree but I still wouldn't want to do it. (Norwich, risk-risk trade-off)

It is important to emphasize that for most people reluctant acceptance was also manifest in a rejection or at least questioning of the parameters of the risk-risk trade-off, recognizing that other potential policy framings could and should exist. Similarly, focus groups and workshops on energy policy commissioned by the DTI, to inform the preparation of the White Paper, observed that there was a large body of "concerned but undecided opinion" on nuclear power, noting the emergence of a highly conditional view around nuclear power, "with acknowledgement that the technology won't go away, alongside a reluctance to accept it except under very stringent conditions" (DTI, 2002: 22).

For about a fifth of participants, the trade-off scenario was simply not tenable-under any circumstances. In both cases, participants drew on a similar set of discursive practices. Substituting one risk for another was, consistent with some of the counter claims mobilized by environmental groups, not a readily acceptable solution to resolving the problems of climate change. Given the intense and deeply held negative cultural associations that nuclear power and waste carried (described earlier) a few people, whilst recognizing the climate 
change problem, reasoned that sooner or later there would be a price to pay for making a trade-off with nuclear power (and waste). This corresponds with Gamson's (1992) notion of a "devil's bargain" discourse: that expanding the nuclear power sector represents a Faustian pact, there are benefits (for instance climate change mitigation) but the costs will be heavy. "We are damned if we do and damned if we don't" (Gamson, 1992: 237).

Martin: Yes, I mean they've [fossil fuel and nuclear power] both got their issues haven't they. They've both got their fundamental problems ... Obviously, with the storage of the nuclear waste and obviously with the greenhouse effect. (Cromer, risk-risk trade-off)

Beyond a comparison that stressed the fear associated with radioactive waste/nuclear power, people often drew comparisons with other available sources of energy in terms of their more limited physical consequences or impacts. This "rational" risk assessment discourse functioned as the basis for rejecting the nuclear option:

Mark: If a gas-fired power station blows up it devastates a few square miles, maybe at most, but if a nuclear power station goes up then it devastates hundreds of square miles for hundreds of years. (Norwich, risk-risk trade-off)

In rejecting this either/or scenario, people repeatedly proposed alternative policy framings, stressing the integration of a range of options or a diversified energy strategy: heavy investment in renewable sources, energy conservation and a mix of energy sources. It was an approach that for a sizeable number of participants included a (mostly temporary) reliance on and toleration of nuclear power-until better alternatives were more established (cf. Loughhead, 2005; King, quoted in McCarthy, 2005).

Craig: I suppose the best way forward has got to be renewable sources, solar power, wave and wind. But I don't think that we're there yet or we're even remotely there yet ... So I think it's inevitable for the near future-you've gotta have some nuclear, you've gotta have some fossil fuels and you've gotta really hit the renewable sources as much as we can. (Liverpool, radioactive waste)

A recent ICM opinion poll does offer some support for the sorts of citizen (counter) frames we have identified. When asked "which source of energy was the most feasible way of meeting the UK's future energy demands while reducing Carbon Dioxide emissions" 57 percent of respondents stated renewables such as wave, tidal, solar and wind power. A further 21 percent also identified an important role for nuclear power (BBC News Online, 2005a). Linking such findings with our own data, a MORI poll conducted for EDF Energy, the UK arm of the French utility company, showed that 55 percent of those questioned believed that old nuclear power plants should be replaced with a mix of new nuclear stations and other renewable sources of energy such as wind power (Murray-Watson, 2005a). Importantly, the survey also revealed that 54 percent agreed with the statement that "although nuclear energy has disadvantages, the country needs it as part of the energy balance, with coal, gas and wind power" (Murray-Watson, 2005a). Such data are strongly suggestive of a sizeable citizen response of reluctant acceptance.

The key issue that we wish to stress from these responses, albeit limited in their number and depth, is that whilst we do see a degree of reluctant acceptance in how people personally and collectively negotiate the reframing of nuclear power, these remarks also express considerable ambivalence and are very far from an uncritical support for a policy frame that rests solely upon a risk-risk trade-off between radioactive waste and climate change. 


\section{Conclusions}

In this paper, we have drawn upon a recent mixed-methods study of citizen views about climate change and radioactive waste risks to consider some possible citizen responses to the increasingly apparent policy reframing of nuclear power (by the nuclear industry, science and increasingly government) which asserts its role in climate change mitigation and as such pushes the technology back to the heart of the energy futures debate-labeled by some commentators "the nuclear renaissance" (e.g. Marshall, 2005). Both the survey and focus group data from this study underline that in isolation people made sense of the two problems in very different ways. The impacts of climate change lacked personal immediacy: the issue was considered important but not worrying (cf. Hinchliffe, 1996). By contrast, radioactive waste was associated with intense dread and fear-rooted in an historical iconography of catastrophe, death, and institutional failure that brought personal salience to the issue. The benefits associated with the causes of climate change, in contrast to those of the causes of radioactive waste, also linked to strongly held and immediate positive cultural values. These data would tend to suggest that a risk-risk trade-off between radioactive waste and climate change would not sit comfortably or resonate with the ways in which citizens were framing the two risk issues or problems.

The second set of issues that we have linked to citizen views of the two risk cases relates to trust in expertise and evaluations of government. We observed very similar patterns of relationships in terms of institutional skepticism-which we suggest can be traced, in part, to the problematic experience of science and technological decision-making in the UK over the past two decades. Whilst science and expertise in the abstract were invested with confidence and a privileged position in decision-making, their blurring with the agendas of politics and business in particular situations undermined this credibility. Government institutions were seen to be unreliable, secretive and failing to execute their proper duties (or functions) to serve the public interest. It is hard to see how in the UK at least, against such a backdrop of widespread perceptions of institutional recreancy and suspicion regarding the play of vested interests, a policy reframing of nuclear power in terms of climate change mitigation would be willingly accepted by an uncritical citizenry. Without recognizing and attending to these underlying structural and institutional problems, we argue that such a policy rhetoric might all too readily be interpreted as a manipulative strategy aimed at legitimizing underlying political and economic drivers.

Our analysis of people's qualitative responses to the question of a risk-risk trade-off, although provisional in nature and not explicitly framed in terms of current political rhetoric, lends support to some of these insights. Only two of 32 individuals consistently viewed expansion in the nuclear power sector as an acceptable route to mitigating climate change. Certainly a larger number, stepping back from intensely negative responses to the issue of radioactive waste (and nuclear power), demonstrated a far more reluctant, uncomfortable, acceptance of the trade-off as the lesser of two evils. Clearly, we might anticipate that such citizen reframings would, as political debate gathers steam, become backgrounded in the routines of social discourse and interaction (Miller, 2000). In fact, other emerging pro-nuclear reframings - which assert nuclear power as the only way of ensuring energy security, countering landscape destruction (see, for instance Murray-Watson, 2005b), and delivering (sufficient) cheap energy - are likely to prove powerful rhetorics for enrolling new adherents, both citizens and other actors. Indeed, a media report recently linked the positive swing in UK citizens' perceptions of nuclear power to support for new nuclear build expressed by a number of leading scientists and politicians (Jameson, 2005). Nonetheless, our data are very far from a signal of citizen support, revealing a complexity of response which if missed or ignored will 
only compound the sorts of problems around the governance of science and technology witnessed in the UK over the past 20 years. In this regard, we have pointed to a number of critical counter-frames (safety, environmental, economic and alternative sources) deployed by citizens and other protagonists in response to the policy discourse(s) of new nuclear build.

The conclusions that we have been able to draw from this exploratory study highlight the need for more detailed (quantitative and qualitative) research that specifically examines how citizens respond to the various reframings of the nuclear power issue (and its waste problem) in terms of sustainability and climate change mitigation and other issues (such as energy security). It is worth noting that citizen arguments against the risk-risk trade-off did not overtly connect to wider skepticism of the accountability and interests of government institutionsalthough such concerns may well have held a tacit, mediating role. The ways in which trust relations mediate citizen reactions to policy (re)framings is an issue worthy of further empirical study and theoretical development.

At the same time, we also need to think critically about how attention to citizen views of new political discourses around new nuclear build (such as the opinion poll data we have reported on) moderate or alter the original policy (re)framing. Recent government rhetoric, that stresses that any new nuclear build would be limited to "one generation only" (King, quoted in McCarthy, 2005) with a much-expanded renewables sector taking on the burden of the UK's carbon-free future, is perhaps suggestive that citizen concerns have informed a more nuanced, and arguably more publicly acceptable, reframing (McCarthy, 2005). Research is thus needed which sets the investigation of citizen responses within a broader, dynamic analysis of the ways in which issue framings are produced and mobilized by different actors; the events that trigger change as well as the discursive and political coalitions that are formed across actor networks, to enroll adherents and to stabilize dominant (or taken-for-granted) framings whilst marginalizing others. It is within this context that one may examine how and why different frames resonate with wider constituencies (most notably citizens) and, crucially, the political and democratic significance of such efforts for risk decision-making.

How far our findings are transferable to other industrial countries, grappling with similar problems and (possible) solutions, is another issue that requires fuller empirical investigation. For instance, differences in relations between civic society and political institutions (e.g. levels of trust), the nature of debate around climate change (historically very different in the United States), relative dependency on the nuclear sector, whether new build would be publicly or privately financed, and the (historical) level of support for nuclear power may well produce distinct (re)framings of the nuclear "solution"- - and (re)framings that differ in their wider societal resonance. ${ }^{5}$ Developing cross-cultural comparisons that explore these contrasting situations is important not only from the perspective of analyzing the governance of environmental risks (such as nuclear power and climate change) but also in terms of theorizing the dynamic political, cultural and material processes through which the framing and reframing of risk occurs (cf. Jasanoff, 2005; Miller, 2000). At this critical time, with the rising political and social prominence of climate change (mitigation), the phasing out of the civil nuclear power sector and wider concerns over energy security, there is, we maintain, a pressing need for such research.

What our analysis does also point to is an important role for stakeholder and citizen dialogue which genuinely engages with these emergent (and multiple) framings of expansion of the nuclear energy sector, climate change mitigation, and particularly how these two issues are increasingly being bound together. Indeed, our own focus group design (with three distinct phases) can be seen as one means of prompting such deliberation. If we want to understand more about stakeholder involvement and how these activities could contribute to problem solving, one of the first steps has to be to identify processes shaping the ways in which different stakeholders view the issue-the problem and in particular the solution(s). Developing 
constructive debate would in this sense be contingent on building deliberative fora through which different stakeholders or citizens could genuinely reflect on how issues are being framed, by whom and to what ends. Such processes of frame reflection (Schön and Rein, 1994; Jasanoff, 2003), enabling parties to scrutinize their own positions, values and principles in relation to those of others, can facilitate the identification and negotiation of more effective and inclusive (and as such acceptable) societal responses to what are very complex socio-technological risks-which on some level will inevitably involve difficult trade-offs.

\section{Acknowledgement}

Work reported in this paper was in part supported by the Programme on Understanding Risk funded by a grant from the Leverhulme Trust (F/00 204/E/), and in part supported by two grants from the Economic and Social Research Council's Science in Society program (L144250037 and RES-336-25001).

\section{Notes}

1 The recent reports by the Royal Commission on Environmental Pollution and the International Panel on Climate Change identified the need to reduce greenhouse gas emissions to these levels to avoid some of the worst effects of climate change (see DTI et al., 2003: 25).

2 This phrase has been mobilized by other scientific/"expert" proponents of nuclear new build (Barry, 2005; Loughhead, 2005) and picked up in media reports (e.g. Black, 2005; Connor, 2005; Fleming, 2005).

3 Recruiters were provided with a "recruitment" questionnaire to assist in the organization of demographically mixed groups and to ensure that individuals working in professions relating to the topic issues were not recruited. Participants received a token payment for contributing to the research.

4 We approached the issue of new nuclear build as a generic concept and therefore did not seek to explore social acceptability at different scales of analysis. It is, however, worth noting that none of our focus group participants used spatial proximity as a criterion for assessing the risk-risk trade-off scenario.

5 For instance, even when asked whether they would favor nuclear power as a way of dealing with climate change, a majority of the American public remains opposed (Rosa, 2004).

\section{References}

Alhakami, A.S. and Slovic, P. (1994) "A Psychological Study of the Inverse Relationship between Perceived Risk and Perceived Benefit," Risk Analysis 14: 1085-96.

Barry, R. (2005) “Special Report: Plugging the Energy Gap,” Prospect November: 50-4.

BBC News Online (2004a) "Climate Issue 'Critical' to Blair," 27 April, URL: http://news.bbc.co.uk/1/hi/uk/3662 303.stm (accessed November 2005).

BBC News Online (2004b) "UK Failing on Greenhouse Gases," 8 December, URL: http://news.bbc.co.uk/1/hi/ uk_politics/4077193.stm (accessed November 2005).

BBC News Online (2005a) "Government Forces EU CO2 Rethink," 23 November, URL: http://news.bbc.co.uk/1/hi/ uk/4462614.stm (accessed November 2005).

BBC News Online (2005b) “PM ‘Convinced' on Nuclear Future,” 21 November, URL: http://news.bbc.co.uk/1/hi/ business/4454468.stm (accessed November 2005).

BBC News Online (2005c) "Poll Shows Opposition to Nuclear Power," 16 May, URL: http://news.bbc.co.uk/1/hi/ programmes/newsnight/4552177.stm (accessed November 2005).

Benford, R.D. and Snow, D.A. (2000) "Framing Processes and Social Movements: an Overview and Assessment," Annual Review of Sociology 26: 611-39.

Bickerstaff, K. and Walker, G. (2002) "Risk, Responsibility and Blame: an Analysis of Vocabularies of Motive in Airpollution(ing) Discourses," Environment and Planning A 34: 2175-92.

Black, R. (2003) "Nuclear University Promotes Atom Power," BBC News Online 5 September, URL: http://news.bbc. co.uk/2/hi/science/nature/3083382.stm (accessed November 2005).

Black, R. (2005) “Britain Facing Large Energy Gap,” BBC News Online 9 September, URL: http://news.bbc.co.uk/1/ hi/sci/tech/4423456.stm (accessed November 2005).

Blair, T. (2004) "Full Text: Tony Blair's Speech," Guardian Unlimited 1 September, URL: http://politics.guardian.co. uk/labour/story/0,,1295054,00.html (accessed November 2005). 
Blake, J. (1999) “Overcoming the 'Value-Action Gap' in Environmental Policy: Tensions between National Policy and Local Experience,” Local Environment 4: 257-79.

Boholm, A. (1998) "Visual Images and Risk Messages: Commemorating Chernobyl," Journal of Risk, Decision and Policy 3: 125-43.

Bord, R.J., O’Connor, R.E. and Fisher, A. (2000) "In What Sense Does the Public Need to Understand Global Climate Change?," Public Understanding of Science 9: 205-18.

British Nuclear Industry Forum (BNIF) (2001) "British Nuclear Industry Forum Submission to the Energy Policy Review: Executive Summary,” URL: http://www.niauk.org/article_13.shtml (accessed November 2005).

British Nuclear Industry Forum (BNIF) (2002) “Nuclear Energy: Talking Points," URL: http://www.niauk.org/downloads/talkgpnt.pdf (accessed November 2005).

Bulkeley, H. (2000) "Common Knowledge? Public Understanding of Climate Change in Newcastle, Australia," Public Understanding of Science 9: 313-33.

Bulkeley, H. (2001) "Governing Climate Change: the Politics of Risk Society?," Transactions of the Institute of British Geographers 26: 430-47.

Bullock, H. (2005) "Melting Down the Myths," Green Futures March/April: 38-42.

Charter, D. (2005) "Nuclear Option Splits Cabinet," The Times Online 9 May, URL: http://www.timesonline.co.uk/ article/0,,19809-1604522,00.html (accessed November 2005).

Connor, S. (2005) "New Nuclear Power Plants 'Essential' to Avoid Energy Shortfall," The Independent Online 10 November, URL: http://news.independent.co.uk/environment/article326056.ece (accessed November 2005).

Department for Environment, Food and Rural Affairs (DEFRA) (2001) "3NC-The UK's Third National Communication under the United Nations Framework Convention on Climate Change," URL: http://www.defra.gov.uk/environment/climatechange/3nc/pdf/climate_3nc.pdf (accessed November 2005).

Department for Environment, Food and Rural Affairs (DEFRA) (2005) "Provisional 2004 UK Climate Change Sustainable Development Indicator and 2003 Air Pollutant Emissions Final Figures," URL: http://www.defra. gov.uk/news/2005/050331a.htm (accessed November 2005).

Department of Trade and Industry (DTI) (2002) "Integrated Public and Stakeholder Consultation to Inform the Energy White Paper: a Process Designed and Managed by IPPR, UK CEED, New Economics Foundation and Dialogue by Design on behalf of the DTI," URL: http://www.dti.gov.uk/energy/developep/int_public_and_ stake_con_rep.pdf (accessed November 2005).

Department of Trade and Industry (DTI) (2003) "Nuclear Power Generation Development and the UK Industry," URL: http://www.dti.gov.uk/energy/nuclear/technology/history.shtml (accessed November 2005).

Department of Trade and Industry (DTI), Department for Transport (DfT) and Department for Environment, Food and Rural Affairs (DEFRA) (2003) "Our Energy Future-Creating a Low Carbon Economy," URL: http://www.dti.gov.uk/energy/whitepaper/ourenergyfuture.pdf (accessed November 2005).

Earle, T.C. and Cvetkovich, G. (1995) Social Trust: Toward a Cosmopolitan Society. Westport: Praeger.

Erikson, K.E., Colgazier, W. and White, G.F. (1994) “Nuclear Waste's Human Dimension," Forum for Applied Research and Public Policy 9: 91-7.

Evans, E., Ashley, R., Hall, J., Penning-Rowsell, E., Saul, A., Sayers, P., Thorne, C. and Watkinson, A. (2004) Foresight, Future Flooding. Scientific Summary: Volume I-Future Risks and their Drivers. London: Office of Science and Technology.

Fleming, N. (2005) "Nuclear Power is Best, Say Scientists," Daily Telegraph Online 10 November, URL: http://www.telegraph.co.uk/news/main.jhtml?xml=/news/2005/11/10/nuke10.xml\&sSheet=/news/2005/11/10/i xhome.html (accessed November 2005).

Flynn, J. (2003) "Nuclear Stigma," in N. Pidgeon, R.E., Kasperson and P. Slovic (eds) The Social Amplification of Risk, pp. 326-52. Cambridge: Cambridge University Press.

Friends of the Earth (FoE) (2004) "Briefing: Why Nuclear Power is not an Achievable and Safe Answer to Climate Change," URL: http://www.foe.co.uk/resource/briefings/nuclear_power_answer_climate_change.pdf (accessed April 2006).

Freudenburg, W.R. (1993) "Risk and Recreancy: Weber, the Division of Labor, and the Rationality of Risk Perceptions," Journal of Social Issues 71: 909-32.

Gamson, W.A. (1992) Talking Politics. New York: Cambridge University Press.

Gamson, W.A. and Modigliani, A. (1989) "Media Discourse and Public Opinion on Nuclear Power," American Journal of Sociology 95: 1-37.

Gow, D. (2004) "EC Backs Off Nuclear Shutdown," Guardian Unlimited 9 September, URL: http://www.guardian.co.uk/business/story/0,,1300159,00.html (accessed November 2005).

Greenpeace (2005) "Ditch the Dodgy Nukes!," URL: http://www.greenpeace.org.uk/contentlookup.cfm?UCID Param $=20051108164401 \& C F I D=3445150 \& C F T O K E N=70486121$ (accessed November 2005).

Hajer, M.A. (1995) The Politics of Environmental Discourse: Ecological Modernization and the Policy Process. Oxford: Clarendon Press. 
Hall, B. (2005) "Blair Urged to Clarify Strategy on Nuclear Fuel," Financial Times Online 15 May, URL: http://news.ft.com/cms/s/57d703de-c576-11d9-87fd-00000e2511c8.html\# (accessed November 2005).

Harrison, C., Burgess, J. and Filius, P. (1996) "Rationalising Environmental Responsibilities: Lay Publics in the UK and Netherlands," Global Environmental Change 6: 215-34.

Hennessy, P. and Langton, J. (2005) "Why Kyoto Will Never Succeed, by Blair," Daily Telegraph Online 25 September, URL: http://www.telegraph.co.uk/news/main.jhtml?xml=/news/2005/09/25/nkyoto25.xml\&sSheet $=$ /portal/2005/09/25/ixportal.html (accessed November 2005).

HM Government (2006) “Climate Change: the UK Programme 2006," URL: http://www.defra.gov.uk/enviroment/ climatechange/UK/ukccppdf/ukcc06-all.pdf (accessed June 2006).

Hetherington, J. (1998 [1997]) "Nirex and Deep Disposal: The Cumbrian Experience," in F. Barker (ed.) Management of Radioactive Waste: Issues for Local Authorities, pp. 17-33. London: Thomas Telford.

Hinchliffe, S. (1996) "Helping the Earth Begins at Home," Global Environmental Change 6: 53-62.

Hinchliffe, S. (1997) "Locating Risk: Energy Use, the 'Ideal' Home and the Non-ideal World," Transactions of the Institute of British Geographers 22: 197-209.

Houghton, J.T., Meira Filho, L.G., Callander, B.A., Harris, N., Kattenberg, A. and Maskell, K., eds (1996) Climate Change 1995: The Science of Climate Change. Contribution of Working Group I to the Second Assessment Report of the Intergovernmental Panel on Climate Change. Cambridge: Cambridge University Press.

Houghton, J.T., Ding, Y., Griggs, D.J., Noguer, M., van der Linden, P.J., Dai, X., Maskell, K. and Johnson, C.A., eds (2001) Climate Change 2001: The Scientific Basis. Contribution of Working Group 1 to the Third Assessment Report of the Intergovernmental Panel on Climate Change. Cambridge: Cambridge University Press.

House of Commons Trade and Industry Committee (1998) Energy Policy: Fifth Report of the House of Commons Trade and Industry Committee, Session 1997-98. London: The Stationery Office.

House of Lords Select Committee on Science and Technology (1999) Third Report: Management of Nuclear Waste. London: The Stationery Office.

Hulme, M., Jenkins, G.J., Lu, X., Turnpenny, J.R., Mitchell, T.D., Jones, R.G., Lowe, J., Murphy, J.M., Hassell, D., Boorman, P., McDonald, R. and Hill, S. (2002) Climate Change Scenarios for the United Kingdom: the UKCIP02 Scientific Report. Norwich: Tyndall Centre for Climate Change Research.

Hunt, J. and Simmons, P. (2001) The Front of the Front End: Mapping Public Concerns about Radioactive Waste Management Issues: Report to Nirex. Lancaster: Lancaster University, Centre for the Study of Environmental Change.

Jameson, A. (2004) “Britain Must Go Nuclear, Energy Chief Tells Ministers," The Times Online 14 September, URL: http://www.timesonline.co.uk/article/0,2-1261215,00.html (accessed November 2005).

Jameson, A. (2005) "Poll Shows Renewed Support for a Nuclear Programme," The Times Online 18 January, URL: http://www.timesonline.co.uk/article/0,,5-1445208,00.html (accessed November 2005).

Jasanoff, S. (2003) “Technologies of Humility: Citizen Participation in Governing Science,” Minerva 41: $223-44$.

Jasanoff, S. (2005) Designs on Nature. Princeton, NJ: Princeton University Press.

Johnson, B.B. (1999) "Exploring Dimensionality in the Origin of Hazard-related Trust," Journal of Risk Research 2: 325-54.

Kirby, A. (2004) "UK Charged with Nuclear 'Fudge,", BBC News Online 11 June, URL: http://news.bbc.co.uk/1/ hi/sci/tech/3798599.stm (accessed November 2005).

Kirup, J. (2005) "Minister Gives Strong Hint in Favour of Nuclear Power," The Scotsman 28 September, URL: http://news.scotsman.com/topics.cfm?tid=52\&id=2004562005 (accessed November 2005).

Knight, R. (2003) "Sitting on the Fence: the Undecided Control the Balance of Opinion about Nuclear Energy in Britain: Report of MORI Poll," URL: http://www.mori.com/pubinfo/rk/sitting-on-the-fence.shtml (accessed November 2005).

Leake, J. and Box, D. (2005) "The Nuclear Charm Offensive," New Statesman 23 May, URL: http://www.newstatesman.com/200505230004 (accessed November 2005).

Lorenzoni, I. and Pidgeon, N.F. (2006) "Public Views on Climate Change: European and USA Perspectives," Climatic Change, 77: 73-95.

Lorenzoni, I., Leiserowitz, A., Doria, M., Poortinga, W. and Pidgeon, N. (2006) "Cross National Comparisons of Image Associations with 'Global Warming' and 'Climate Change' among Laypeople in the United States of America and Great Britain,” Journal of Risk Research 9(3): 265-81.

Loughhead, J. (2005) "How to Plug the Energy Gap: News Release PR60," The Geological Society 10 November, URL: http://www.geolsoc.org.uk/template.cfm?name=PR60 (accessed November 2005).

Lovell, J. (2005) “Ageing Nuclear Stations Must be Renewed-Scientists," Reuters UK 10 November, URL: http://today.reuters.co.uk/news/news Article.aspx?type=topNews\&storyID=2005-11-10T001532Z_01_ SCH000775_RTRUKOC_0_UK-BRITAIN-NUCLEAR.xml (accessed November 2005). 
McCarthy, M. (2005) "Nuclear Power May be the only Way, Says Chief Scientist," The Independent Online 12 May: http://news.independent.co.uk/environment/article221142.ece (accessed November 2005).

McDaniels, T., Axelrod, L.J. and Slovic, P. (1996) "Perceived Ecological Risks of Global Change—a Psychometric Comparison of Causes and Consequences," Global Environmental Change 6: 159-71.

Marris, C., Langford, I.H. and O'Riordan, T. (1998) “A Quantitative Test of the Cultural Theory of Risk Perceptions: Comparison with the Psychometric Paradigm," Risk Analysis 18: 635-47.

Marshall, E. (2005) "Is the Friendly Atom Poised for a Comeback?," Science 309: 1168-9.

May, R. (2004) "We Need More Nuclear Power Stations, Not Wishful Thinking," Daily Telegraph Online 15 September, URL: http://www.opinion.telegraph.co.uk/opinion/main.jhtml?xml=/opinion/2004/09/15/do1501. $\mathrm{xml}$ (accessed November 2005).

Michael, M. (1992) "Lay Discourses of Science: Science-in-General, Science-in-Particular, and Self," Science, Technology and Human Values 17: 313-33.

Michael, M. (1996) "Ignoring Science: Discourses of Ignorance in the Public Understanding of Science," in I. Irwin and B. Wynne (eds) Misunderstanding Science? The Public Reconstruction of Science and Technology, pp. 107-25. Cambridge: Cambridge University Press.

Miller, C. (2000) "The Dynamics of Framing Environmental Values and Policy: Four Models of Societal Processes," Environmental Values 9: 211-33.

Milner, M. (2005) "Britain Needs a Debate on Nuclear Energy, Say Industry Leaders," Guardian Unlimited 21 November, URL: http://www.guardian.co.uk/nuclear/article/0,2763,1647261,00.html (accessed November 2005).

Monbiot, G. (2004) "Comment: There is an Alternative," The Observer 7 September, URL: http://www.guardian.co. uk/nuclear/article/0,2763,1298593,00.html (accessed November 2005).

Morgan, O. (2005a) "Labour Readies Ground for New Wave of Nuclear Stations," The Observer 2 October, URL: http://observer.guardian.co.uk/business/story/0,6903,1582705,00.html (accessed November 2005).

Morgan, O. (2005b) "Secret Papers Reveal New Nuclear Building Plan," The Observer 8 May, URL: http://observer.guardian.co.uk/business/story/0,6903,1479279,00.html (accessed November 2005).

Mukherjee, S. (2005) “Analysis: Do We Need Nuclear?," BBC News Online 26 April, URL: http://news.bbc.co.uk/2/ hi/uk_news/politics/vote_2005/frontpage/4483745.stm (accessed November 2005).

Murray-Watson, A. (2005a) "Britons Back New Nuclear Plants," Daily Telegraph Online 6 November, URL: http://money.telegraph.co.uk/money/main.jhtml?xml=/money/2005/11/06/cnucl06.xml (accessed November 2005).

Murray-Watson, A. (2005b) "Labour Plots New Nuclear Power Plants," Daily Telegraph Online 30 January, URL: http://www.telegraph.co.uk/money/main.jhtml?xml=/money/2005/01/30/cnnuke30.xml (accessed November 2005).

Parliamentary Office of Science and Technology (POST) (2003) "The Nuclear Energy Option in the UK," URL: http://www.parliament.uk/documents/upload/postpn208.pdf (accessed November 2005).

Phillips, Lord, Bridgeman, J. and Ferguson-Smith, M. (2000) The BSE Inquiry: Report, Evidence and Supporting Papers of the Inquiry into the Emergence and Identification of Bovine Spongiform Encephalopathy (BSE) and Variant Creutzfeldt-Jakob Disease (vCJD) and the Action Taken in Response to it up to 20 March 1996. London: The Stationery Office.

Poortinga, W. and Pidgeon, N.F. (2003a) "Exploring the Dimensionality of Trust in Risk Regulation," Risk Analysis 23: 961-72.

Poortinga, W. and Pidgeon, N.F. (2003b) Public Perceptions of Risk, Science and Governance: Main Findings of a British Survey on Five Risk Cases (Technical Report). Norwich: Centre for Environmental Risk.

Poortinga, W. and Pidgeon, N.F. (2005) "Trust in Risk Regulation: Cause or Consequence of the Acceptability of GM Food?," Risk Analysis 25: 199-209.

Renn, O. and Levine, D. (1991) "Credibility and Trust in Risk Communication," in R.E. Kasperson and P.M. Stallen (eds) Communicating Risks to the Public, pp. 175-218. Amsterdam: Kluwer.

Ritch, J. (2005) "Organising for the Nuclear Renaissance: the Role of the WNA," Presented at the World Nuclear Fuel Cycle Conference, 13 April, San Antonio, TX. URL: http://www.world-nuclear.org/dgspeeches/sanantonio130405.htm (accessed November 2005).

Roche, P. (2005) "Is Nuclear Power a Solution to Climate Change?," URL: http://www.no2nuclearpower.org. uk/reports/Nuclear_Power_April_05v2.pdf (accessed November 2005).

Rosa, E. (2004) The Future of Social Acceptability of Nuclear Power in the United States. Paris: Institute Francais des Relations Internationales.

Royal Society and Royal Academy of Engineering (1999) "Nuclear Energy-the Future Climate," URL: http://www.royalsociety.org/document.asp?tip=1\&id=1464 (accessed November 2005).

Schön, D. and Rein, M. (1994) Frame Reflection: Toward the Resolution of Intractable Policy Controversies. New York: Basic Books. 
Slovic, P. (2000) The Perception of Risk. London: Earthscan.

Slovic, P., Layman, M., Kraus, N., Flynn, J., Chalmers, J. and Gesell, G. (1991) "Perceived Risk, Stigma, and Potential Economic Impacts of a High-level Nuclear Waste Repository in Nevada," Risk Analysis 11: 683-96.

Slovic, P., Finucane, M.L., Peters, E. and MacGregor, D.G. (2004) "Risk as Analysis and Risk as Feelings: Some Thoughts about Affect, Reason, Risk, and Rationality," Risk Analysis 24: 311-22.

Sustainable Development Commission (2004) Shows Promise. But Must Try Harder. An Assessment by the Sustainable Development Commission of the Government's Reported Progress on Sustainable Development over the Past Five Years. London: Sustainable Development Commission.

Ungar, S. (2000) "Knowledge, Ignorance and the Popular Culture: Climate Change Versus the Ozone Hole," Public Understanding of Science 9: 297-312.

Vidal, J. (2004) "Nuclear Plants Bloom," Guardian Unlimited 12 August, URL: http://www.guardian.co.uk/life/feature/story/0,,1280884,00.html (accessed November 2005).

Walls, J., Pidgeon, N.F., Weyman, A. and Horlick-Jones, T. (2004) "Critical Trust: Understanding Lay Perceptions of Health and Safety Risk Regulation," Health, Risk and Society 6: 133-51.

Ward, N., Donaldson, A. and Lowe, P. (2004) "Policy Framing and Learning the Lessons from the UK's Foot and Mouth Disease Crisis," Environment and Planning C: Government and Policy 22: 291-306.

Weart, S.P. (1988) Nuclear Fear: A History of Images. Cambridge, MA: Harvard University Press.

Wilson, B. (2004) "Face the Facts: The Future Must be Nuclear," The Observer 22 August, URL: http://observer.guardian.co.uk/business/story/0,6903,1288131,00.html (accessed November 2005).

Wilson, B. (2005) "A Question We Can Duck no Longer," The Observer 8 May, URL: http://observer.guardian.co.uk/ business/story/0,6903,1478844,00.html (accessed November 2005).

Wintour, P. and Brown, P. (2004) "Blair Reignites Nuclear Debate," Guardian Unlimited 7 July, URL: http://www.guardian.co.uk/print/0\%2C3858\%2C4965160-103690\%2C00.html (accessed November 2005).

Wintour, P. and Milner, M. (2005) "Cabinet Challenge to Nuclear Proposals," Guardian Unlimited 1 October, URL: http://www.guardian.co.uk/nuclear/article/0,2763,1582561,00.html (accessed November 2005).

Woolf, M. (2005) "Blair Demands Nuclear Power to Protect High 'Living Standards,"” The Independent Online 9 May, URL: http://www.commondreams.org/headlines05/0509-09.htm (accessed November 2005).

World Nuclear Association (2004) "Nuclear, Climate Friendly Energy," URL: http://www.niauk.org/article_26.shtml (accessed November 2005).

Zonabend, F. (1993) The Nuclear Peninsula. Cambridge: Cambridge University Press.

\section{Authors}

Karen Bickerstaff is a Lecturer at the Department of Geography at Durham University, UK. Her research interests address the social and spatial factors that influence the experience "risk," the spatial politics of environmental controversy and the outcomes of recent experiments in public and stakeholder engagement. Correspondence: Department of Geography, University of Durham, Durham DH1 3LE, UK; e-mail at k.j.bickerstaff@durham.ac.uk

Irene Lorenzoni is a Senior Research Associate at the School of Environmental Sciences, University of East Anglia (Norwich, England), associated with the Tyndall Centre for Climate Change Research. Irene's research interests stem from a strong drive to understand responses to climate change at individual and institutional levels. Recently, she led work developing and undertaking a strategic assessment of scientific and behavioral perspectives of dangerous climate change. Other research has focused upon cognitive factors and constraints influencing behavioral responses to climate change. Irene has also contributed to research on public and stakeholder participation.

Nick Pidgeon is Professor of Applied Psychology at Cardiff University, Wales, UK. He has current research interests in risk perception and risk communication across a range of technological controversies including genetically modified agriculture, nuclear power, climate change and nanotechnologies. He has also researched deliberative and stakeholder processes for addressing public policy decisions in science and technology. 
Wouter Poortinga is Academic Fellow at the Welsh School of Architecture, Cardiff University, UK. His main research interests are in environmental behavior, risk perception research, and environment and health.

Peter Simmons is a Lecturer with the School of Environmental Sciences at the University of East Anglia, UK. His current research interests focus on two main areas: stakeholder involvement in decision-making about environmental and technological risk; and the relationship between place, identity and situated technological risk. 